\title{
Collapsing Architecture Towers, Steeples, and Minarets as War Monuments
}

\author{
Ruggero Ragonese \\ Università di Modena e Reggio Emilia \\ ruggero.ragonese@unimore.it
}

\begin{abstract}
Tower, Steeples and Minarets can be regarded in the context of an urban landscape: the meaning lies essentially in the upward movement. Vector-oriented constructions capable of arranging the urban space around it. At the same time, however, these buildings include inside various narrative programs: the architectural text presents itself to be read by those who encounter it. The question is whether it can imply an elementary narrative micro-universe. Can towers predict their collapse? This paper will focus on relationships between war and architecture, investigating how certain structures like towers and minarets have inside them specific programs of collapsing related to offences involving weapons.
\end{abstract}

\section{Keywords}

Towers; Point of View; Architecture; War memorials; Urban studies

\section{Contents}

1.The Towers and the City

2. Towers, Minarets, Walls and Wars

3. Conclusion. A Semiotics of Falling

References 
Ruggero Ragonese | Collapsing Architecture. Towers, Steeples, and Minarets as War Monuments

\section{The Towers and the City}

Towers, bell towers and minarets are commonplace buildings. We don't need to describe them. We are familiar with them; they all have a similar architectural form. Evidently, however, they have different functions. The watchtower, whether inside fortifications or standing alone in isolation, is almost always strongly connected to war. These towers are part of the defensive fortifications of towns, castles and military bases. The bell tower and minaret are auxiliary religious architecture. They are located next to the principal religious building. Kevin Lynch's pioneering study has emphasized this aspect of the legibility of a city and has derived a vocabulary for reading the city in terms of paths, nodes, edges, walls, landmarks. According to this classification, towers, minarets, bell towers should be urban landmarks: "a type of point-reference" where "the observer does not enter within them, they are external" (Lynch 1960: 48).

When you approach San Gimignano you will see many tall parallelepipeds rising from the city, but you won't notice any differences at first glance, you almost can't see that some of the structures that look like towers are in fact church steeples. Coming closer one becomes aware of the differences, which are often minimal. The tower is almost always crenellated at the top or is cut off, while the steeple ends in a pitched roof with four triangular sides, its characteristic crown. In San Gimignano there are no minarets, but the resemblance between them and bell towers and steeples is evident; the minaret is thinner than the other two, and is topped by a conical crown. In other words, it is easy to locate a tower, a steeple or a minaret in any given urban area and also easy to confuse them. There is an interesting passage in Vittorini's $L a$ Sardegna come un'infanzia (Sardinia as one's childhood) that seems to highlight this possible confusion:

Campanili ora slanciati e rotondi ma tronchi come minareti di Persia, ora a molti ripiani, con balconate di ferro battuto, proprio come le torri delle chiese messicane. (Vittorini 1974: 180) ${ }^{1}$

Few investigations on the dynamic behavior of minarets exist in the semiotic literature. The minaret is usually considered to be one of the most distinctive features of the Islamic mosque but unlike this, the references to the minaret are very few. Art historical researches focus on the different styles of minarets tops, which have various shapes and names. Only very limited studies have been carried out depend upon especially in engineering concept. Nevertheless, we can agree on: Minarets are towers that are close to or built into mosque structures. Minarets are to mosques what steeples are to churches. Both are towers attached to houses of worship used to call believers to prayer.

1 "Bell towers either with slender round trunks like minarets of Persia; or with many layers and wrought iron balconies, like the towers of Mexican churches" (Vittorini 1974: 180). My translation. 
Ruggero Ragonese | Collapsing Architecture. Towers, Steeples, and Minarets as War Monuments

Towers, steeples, and minarets rise above the other buildings. They are more visible, and thus suffer greater risk in the event of conflict or war. Therefore, beyond the occasionally useless categories created to divide their functions (or types), towers, steeples, and minarets are built from and for war, and bear these traces.

Although definitions and functions vary, one could also simply say that towers, steeples and minarets are tall structures, taller than they are wide, often by a significant factor. This kind of structures are different from a tall building in that they are not built for habitation or for work, but serves other functions, primarily achieved by its height. In semiotic terms, the tower always valorises height compared to a building with a quadrilateral or polygonal base that is greater than, or equal to, its height (e.g. a church, public, private, or monument building) which favours the valorisation of the horizontal over the exploitation of the vertical.

The tower is therefore easily readable in the urban space, and continues to be so even if it is cut off, defaced, reconstructed (e.g. by war). However, urban forms should not be studied as static objects, but as dynamic systems, the structures of which are defined by their constituent elements, and so obviously the final form of a city consists of all the social and spatial patterns, which include historical traces. The vertical force of the tower can hardly hide in a building. There are endless examples of restructured medieval houses in which the tower has been 'hidden' by later additions. It is highly unlikely that the structure disappears altogether. A block separate from the rest of the building remains, reminiscent of the tower's pre-existence. ${ }^{2}$

At this point, given that the tower, the steeple and minaret have had: a) such a long temporal persistence and are so strongly detectable in the urban environment ${ }^{3}$, and b) have had and continue to have defensive and detection functions. One might ask: why not consider them war memorials? A war memorial is an architectural structure intentionally built to commemorate a conflict that has occurred. The tower can be built for war, not to remember a war. It is therefore not $a$ war memorial, but for war Nonetheless, architecture does function as a form of communication. Eco (1968: 64) shows how the secondary function can be more important than the primary function: architectural connotation goes beyond the first meanings and thereby transcends architectural denotation or primary functions. The architectural element carries the story of its conflict, and relationship with war inside itself. So, in the course of history, both primary and secondary functions might be found undergoing losses, recoveries and substitutions of various kinds (cf. Leach 1997). These losses, recoveries and substitutions are common to the life of forms in general, and constitute the only way to understand a process of resemantization in a given architectural structure.

Architectural elements with strong verticality such as the steeples, towers,

2 Across Europe, towers are often served as the starting point for the construction of aristocratic homes (cf. Flori 1998).

3 Regarding the close relationship between monumentality and visibility, see Ragon (1985). 
Ruggero Ragonese | Collapsing Architecture. Towers, Steeples, and Minarets as War Monuments

and minarets, don't only tell us that the verticality has been emphasized. It's an obvious point. They also tell us that the valorisation of the height allows for greater control of the territory. This is explicit in terms of the requested functionality, the type of use that is made of the architectural object. The tower is a structure that allows for the visual control of the territory, the view of the surrounding environment. The steeple allows one to control sound (the bells); from above you can make anything heard. The minaret exerts a similar function, the auditory control of the territory. Within the city out in the countryside, the function of controlling these two primary senses (hearing and sight) was assigned to these actors.

This was not so much against an external enemy, but rather against an internal enemy. In Italian city-municipalities, the tower was not built along the outside walls, but adjacent to individual families' palaces. The reality of their strength and cost showing their lord's power and wealth, in addition to deterring any physical confrontation (Dodds 1999). The tower was not a liminal element of the urban fabric. The skyline of Italian cities was entirely dominated by soaring structures built by private families engaged in deadly conflict with each other (Dobson 2014). Families built defensive towers that studded the urban landscape: "these internal disputes became a standard feature of Italian urban development throughout the Middle Ages and Renaissance" (Kleinhenz 2004: 1111). If ones' rivals made an one hundred feet tower (30 mt), it became necessary to build an one hundred and twenty feet tower (35 $\mathrm{mt})$. Who had the higher tower acquired a practical advantage, he saw farther, could predict the moves of the others, and could dodge ambushes. Above all, however, it had a symbolic advantage: he dominated the others. In this sense, the tower of the town hall, which is often the tallest tower, has a balancing function regarding the other towers. City governments sought to regulate the construction of towers, as this excerpt demonstrates: "If during my term of office any person of the city or suburbs of Lucca builds or causes to be built a tower, whose height exceeds the tower of the sons of Paganello, Baratella and Boccella... of that of sons and grandsons of Bongioro as it now is, I [the podestà l, having measured them, shall absolutely prohibit it from exceeding that measure." (Statutum lucani communis an MCCCVIII in Dean 2000).

Something similar happens for church steeples. There is a definite hierarchy in the height of the bell towers. The taller one has more control (religious and political, but also military as the church is the centre of many municipality conflicts). This hierarchy is respected in Siena, where the Cathedral's steeple towers over the monastic orders' steeples placed at the gates of the city. It is much less respected in other cities. For example, in the cities of the Saints, the most important monastic churches, also peripheral to the centre, have a bell tower that is taller than the cathedral: in Assisi, Padua, Verona.

The towers within a fortification can create relative problems. Stabilized by the surrounding wall structure, the lookout tower in the fortress is usually only slightly taller than the fortification, so that often in these cases we use the term turret. The tower, if it falls, creates little harm in that it: a) is placed away from the city centre; and b) is very short. But what happens if a tall, thin tower, situated in the center of old city, falls? 
Ruggero Ragonese | Collapsing Architecture. Towers, Steeples, and Minarets as War Monuments

The challenging problem is not so much how a tower, a steeple or a minaret collapses, but rather how towers, steeples and minarets anticipate their own collapse. This is an important issue for civil engineers and architects, but may also be of interest to semiotics of space, urban planning and architecture. Observing how an architectural text inscribes its own end within itself helps one to recognize potential methodological traps along the narrative path of a subject inscribed in the architectural text. For example, Manar Hammad traces what was in the third century A.D. the path of the devotee at the shrine of Bel in Palmyra (Hammad 1996): this is the immanent organization of space, when space organizes signification, independently of the actors that enter that space. Topical spaces in the town can have a manipulative role, permitting some certain performative modalities, prohibiting others. However, there is not only one Path in an architectural text. The aspect of incompleteness, especially when the building is not finished or ruined, takes a very important role in the enunciation level. According to Lukken, Hirschfeld, Searle (1993: 37), in architecture "enunciator is not to be identified with the author of text", instead, "the role of enunciatee is played in a certain sense by anyone who looks at the building or uses it." Architecture is spatially and formally configured, and that configuration by ways of semiotic arrangement may shape identity and identification. At the same time, stratification of social discourses and people uses can change the spatial configuration (cf. Lorusso 2015). A sort of hierarchically organized programs:

a) the main sender of the building - architect, client, etc; b) the topical configuration of the building - a first delegated sender c) specific topical configuration, that is introduced by the people using the building - a second-level delegated sender. (Lukken, Hirschfeld, Searle 1993: 52)

According with the point c), it is possible to consider the architectural text as a project: it can configure not only stories and/or and usage programs, but at the same time also tasks of programming and instructing.

\section{Towers, Minarets, Walls and Wars}

For most of the Middle Ages, the problem of the collapse of a tower or a steeple did not arise. In fact, it is in this period that the tower was a metaphor of absolute steadfastness, of unwavering defence. Virgil exhorts Dante in the Divine Comedy, "Sta come torre ferma, che non crolla" / "stand like a sturdy tower that does not shake its summit." (Purgatory, Canto V, vv. 14-15)4. The tower was the most solid defensive architectural structure. Although in many ways a manifestation of private interests of a lord in an urban space, the tower was "a public space in that it functioned as an indicator of public autorithy in urban space" (Christie, Herold 2016: 164).

4 Alighieri, Dante (1984), The Divine Comedy (II. Purgatorio). A verse translation, by Allen Mandelbaum, Toronto, N.Y., Bantam Books. 
Ruggero Ragonese | Collapsing Architecture. Towers, Steeples, and Minarets as War Monuments

Things changed with the construction of offence weapons. ${ }^{5}$ It is curious how little the relationship, rich in meaning, between the development of weapons and the development of architecture (not only defensive architecture, but also public and private) has been investigated, outside the field of engineering. The definitive decline of the tower as a defensive urban symbol was signalled by the opening of shops at its base and the construction of external stairs, things unthinkable in the classic structure (cf. Dean 2000). Between the end of the fifteenth and sixteenth centuries, cities began to lose their towers and often their steeples. The Giotto's Campanile in Florence, which competes with Brunelleschi's dome of Santa Maria del Fiore, was a very significant precursor. The towers were often dismantled, and the bricks and tiles reused for other buildings. Emblematic was the situation in Rome: the city towers, numerous until the sixteenth century, were almost all demolished in order to obtain material for reuse. ${ }^{6}$ The sixteenth and seventeenth centuries were not centuries of towers and steeples. Even St. Peter's bell tower would be demolished in favour of Michelangelo's dome and its four smaller steeples. In the end, the upward momentum of the towers and steeples ran out. There were certainly multiple reasons: the end of the infighting between factions; the need for material for new construction. There was, however, an eminently practical reason, or rather, numerous reasons: they were called mortar, falconet, bombard and later cannon. The towers could be hit. If you take a look at Francesco di Giorgio or Giuliano da Sangallo's defensive treaties, it becomes clear that the problem was not the destruction of a tower, but its fall. Now, the tower might fall and its landing could be disastrous. The quadrangular towers, for instance, are based on four walls (one on each side) where each of these walls is load bearing. In other words, if one collapses, all collapse. The typical fall of these towers is called 'tipping', that is, the whole length of the tower tips tracing a ninety-degree parabola and falls to the ground covering more or less the area of its mass. In addition, the impact of cobblestones or bricks produce chips that can hit people and other neighboring buildings. The tower-house, the tower of a building becomes a tremendous double-edged sword. Built to defend the house, it was now the best instrument with which to destroy it. The defensive strategy of Renaissance cities was based on a new type of fortification system, more complex, promoting larger distances between the city and the enemy lines. This had a direct impact on the structure of the city. The defensive strategy of Renaissance cities was based on a new type of fortification system, more complex, promoting larger distances between the city and the enemy lines and "this had a direct impact on the structure of the city" (Oliveira 2016: 59). Today, towers are to be seen as single scouts or in pairs in Perugia and Bologna; but these are isolated survivors. Steeples, however, often have space around it that will allow it to 'tip'. San Marco's steeple in Venice, one of the largest and most famous, collapsed in 1902 causing, all things considered,

5 Invented in the early fourteenth century, bombards, cannons, falconets grew into so powerful an offensive weapon by the end of the fifteenth that traditional fortification methods had become obsolete (cf. Hale 1983; Krebs 2004).

6 On this subject see Amadei (1931) and Nenci (2001). 
Ruggero Ragonese | Collapsing Architecture. Towers, Steeples, and Minarets as War Monuments

only minor damage to the Evangelist church and the square. San Marco's bell tower was in fact separate from the building of worship, and its fall was already calculated into the eighteenth century organization of the square. In the end, Renaissance heightened the discontinuities of space and time characteristic of the new cities. Familiar landmarks-walls, towers, steeples-seemed out of place, moored to a new urban context (Classen, 2009).

Based on these considerations, it may surprise that just as the towers went out of style, minarets gained popularity in Ottoman Empire during the Sixteenth century, becoming an important element in the urban landscape. Here, Sinān (1489-1578/88), the great architect of Suleiman the Magnificent, even increased the number of his mosques' minarets to four. The Ottoman style was symbolized by the immense Süleymaniye Mosque located on the Third Hill of Istanbul with their sleek pencil-like minarets. However, the success of the Ottoman minaret is no surprising, considering the new features introduced. While the Syrian, Indian and Iranian minaret rests on a similar base to that of a tower, the Turkish minaret reduces the width of the height, assuming the so-called 'needle' form: a very slender cylindrical or prismatic shaft ending in a point and lying on a wider prismatic plinth, to which it is connected by a polyhedral intermediate part. It is important to emphasize that, according to recent studies (DoPangün et al. 2007), the intermediate part between the shaft and the base was the most fragile. So, the Turkish minaret is composed of square stone blocks. Each block is as wide as one side of the perimeter. As it is difficult to find large enough blocks, the Turkish minaret is often polygonal, as the number of perimeter sides increases, the blocks get smaller. So the support design is supported by more actors than the European towers that had only four load-bearing walls. Furthermore, each block does not fully cover the height of each side. The minaret is then divided into orders (generally three, often two) crowned by balustrades. A narrative variable is introduced to the architectural text. Not only are support plans inscribed, not only is the fall envisioned, but the fall itself is modified. The minaret falls in blocks, falls by 'orders'. The material that it is made of, and how the material is arranged, allows for predicting and containing the moment of possible catastrophe. The minaret can loose the conical crown, loose one of the orders, but its collapse is still modulated by its textual structure that marks the breaking points (balustrades), and that creates a plurality of actors (the stone blocks) that share the support function. Furthermore, the architecture is designed to offer the smallest area to enemy fire. In addition, the Turkish minaret, detached from the sacred building, is very light and therefore covers a very limited area in the event it is knocked down. The minaret is a text in which its fall is perfectly legible.

The architectural texts do not only transform themselves due to conflict and the evolution of military strategy. Their 'potential' fall, their destruction, is also marked in their structure. The particular narrative path that leads to its destruction is expected in the text.

So while the medieval tower did not anticipate its fall, the modern tower reorganizes its structure as a function of this possibility. This reorganization can lead, for example, to enhance the area of the base with respect to the height, so that the architectural text assumes a slightly pyramidal form (the Eiffel 
Ruggero Ragonese | Collapsing Architecture. Towers, Steeples, and Minarets as War Monuments

Tower). In other cases the interior is eliminated or lightened, stone stairs are abandoned in favour of simpler iron or wood structures. In yet other cases the least defensible part, the top, is lightened as much as possible, in the case of the tower, or elongated, in the case of the steeple.

\section{Conclusion: A Semiotics of Fall}

All of this provides us with a basis with which to observe the narrative programs within the architectural enunciation, but does not yet explain whether and how the tower, the steeple, the minaret could be war monuments. To achieve this I think we should mention an aspect that engineers and architects have greatly explored, but about which I believe semiotics can also say something: construction material. A semiotics of the material could be very useful because that which builds the architectural text clearly implies a potential narrative path.

The aforementioned Eiffel Tower, for example, uses iron to sustain a strongly modulated structure on three floors. Iron, in fact, brought the revolution in building techniques with the introduction of reinforced cb oncrete. Reinforced concrete buildings are built on a strong metal frame filled with empty (attics, floors) and full (concrete) spaces. Stone, cement and lime are no longer the support elements of the structure; is the iron that supports the structure. With reinforced concrete the concept of the weight-bearing wall disappears. The structure is weight-bearing, not one wall or another. I believe investigating the implications of this disappearance could be fundamental to architectural semiotics.

Reinforced concrete (as we can also see in the metaphor contained in its name in Italian: cemento armato, armed cement) is a material of war and for war. It can withstand the most devastating impacts, including those from shelling. At the beginning of the last century, bunkers were built concrete, the strongholds. New public buildings are constructed of reinforced concrete. Even existing buildings, including churches, aristocratic buildings (even the ruins of the royal palace at Knossos in Crete), and above all, the towers and steeples were reinforced with this new material. The new 'armed' buildings hold up very well in their primary and secondary prospectuses, but also have a vulnerable aspect. The vulnerable and not defendable part is the roof.

The great defeat of reinforced concrete would be the Second World War. Air strikes pass through the roof and gut the house from the inside. This is one of the reasons behind the classical iconography of European cities that appear in archival images as a series of facades without buildings, windows or doors with only the sky behind (i.e. Dresden). In Hiroshima almost everything up to about one mile from was completely destroyed, except for small number (about 50 of heavily reinforced concrete buildings, most of which were specially designed to withstand earthquake shock): most of these buildings "had their interiors completely gutted, and all windows, doors, sashes, and frames ripped out.” (The Manhattan Engineer District, 1946: 11)

For towers and steeples, the story is different, the reduced surface offered to the bombing from above allowed this architecture to resist. It is easy to see, in the cities most affected by the Second World War, how church steeples, as 
Ruggero Ragonese | Collapsing Architecture. Towers, Steeples, and Minarets as War Monuments

well as old and modern towers were the most resistant architecture. At the same time, the insertion of reinforced concrete allowed the structures to withstand side-impact. The reinforced concrete towers modulate their fall in a different way than the Ottoman minarets. The cement becomes a secondary actor to the centrality of the iron structure. What remains is not part of the text or part of the secondary materials, as in the partial 'tipping' of a brick or stone tower. What remains is the structure. It can lose the spaces filled by cement, it can lose part of the internal interstices, but it does not lose the overall structure. This falling plan allows for minimum loss and substantial stability in case of impacts. There are no longer bearing elements, architectural actors that play tasks hierarchically higher than another. A single actor upholds the text. Reinforced concrete introduces a fundamental re-modulation of a fall into the architectural text.

If, however, structures of this type involve a 'fall' narrative program that is limited to a minimum, at the same time, the impossibility of a partial collapse of the structure (as in Turkish minarets) leads to an increased risk of total destruction. If the actor is reduced to one, if you delete the other load-bearing walls, reinforced concrete towers are not more likely to tip over, but 'implode' on themselves. When the only actor ('iron frame') that supports the entire architectural text falls, the text inevitably collapses with him. This was the tragic case of the Twin Towers 2001, which did not have load-bearing walls, but an articulated and unified metal frame. A sort of 'semiotic' black hole "in which language, too, falls short of generating the analogies, similes, tropes and metaphors that would adequately describe it." (Hamdy 2006)

Obviously, architecture of the building includes various narrative programs that can change during the service time of the building. However, the architectural text not only inscribes in itself its own collapsing plan, but also manages to imply a material surviving plan after the fall. We are very close to the category of war memorials of which we spoke about at the beginning. The steeples that rose in Berlin in "45, the truncated minarets in Sarajevo, are war monuments. They are war monuments above all because they contain patterns, as textual strategies of enunciation inscribed in the text, that may transform them practically. This also happens in the case in which (as for the Twin Towers) the type of material chosen (reinforced concrete) envisages total catastrophe: the destruction of the text itself. Maximizing the defence of the integral structure of the tower, it also denies the possibility to exist as a 'part' and as a ruin. The idea of indestructible bastion is originally a war concept, an architectural conceit of invincibility.

Towers, steeples, and minarets are architectural texts that embody (historically, socially, linguistically) the idea of conflict. They draw the traces of conflicts within themselves and develop narrative paths that will not only determine the moments of the fall, but also preserve the memory of their existence and the mode of their destruction. Perhaps this architecture is not, instantly, a war monument, but they can become them. They are monuments to a 'possible', predictable war. ${ }^{7}$

7 An interesting classification of various types of monument can be found in De- 
Ruggero Ragonese | Collapsing Architecture. Towers, Steeples, and Minarets as War Monuments

\section{References}

Amadei, Emma

1931 Le torri di Roma, Spoleto, Panetto e Petrelli.

Christie, Neil; Herold, Hajnalka (eds.)

2016 Fortified Settlements in Early Medieval Europe, Oxford and Philadelphia, Oxbow Books.

Classen, Albrecht

2009 Handbook of Medieval Culture: Fundamental Aspects and Conditions of the European Middle Ages, Vol. III, Berlin and New York: de Gruyter

Dean, Trevor

2000 The Towns of Italy in the Later Middle Ages, Manchester and New York, Manchester University Press.

Debray, Regis

1999 “Trace, forme ou message?", in La confusion des monuments, Cahiers de médialogie, 7, Paris, Gallimard.

Dobson, Chris

2014 The Lost Towers of Florence: A Vanished Medieval Skyline, Suffolk, Dobson.

Dodds, John F.

1999 Bastions and Belligerents: Medieval Strongholds in Northumberland, Newcastle upon Tyne: Keepdate Publishing.

Doğangün, Adem et alia

2007 "Traditional Turkish masonry monumental structures and their earthquake response" in International Journal of Architectural Heritage: Conservation, Analysis, and Restoration I, 3.

Eco, Umberto

1968 La struttura assente, Milano, Bompiani.

Flori, Jean

1998 Chevaliers et chevalerie au Moyen Âge, Paris, Hachette.

Hamdy, Noha

2009 "Revisiting Transmediality: 9/11 Between Spectacle and Narrative" in Säckel, S., Göbel, W., Hamdy, N. (eds.) Semiotic Encounters. Text, Image and TransNation, Amsterdam- New York, Rodopi.

Hale, John Rigby

1983 Renaissance War Studies, London, The Hambledon Press.

Hammad, Manar

1996 Le sanctuaire de Bel à Tadmor-Palmyre, Urbino, Centro internazionale di semiotica e linguistica.

Lorusso, Anna Maria

2015 Cultural semiotics, London, Palgrave Macmillan.

bray (1999). 
Ruggero Ragonese | Collapsing Architecture. Towers, Steeples, and Minarets as War Monuments

Kleinhenz, Christopher (ed.)

2004 Medieval Italy: An Encyclopedia, New York, Routledge.

Krebs, Robert

2004 Groundbreaking scientific experiments, inventions, and discoveries of the middle ages and the Renaissance, Santa Barbara, CA, Greenwood Publishing Company.

Leach, Neil (ed.)

2007 Rethinking Architecture: A Reader in Cultural Theory, London, Routledge.

Lukken, Gerard; Hirschfeld, Yizhar; Searle, Mark

1993 Semiotics and Church Architecture: applying the semiotics of AJ Greimas and the Paris School to the analysis of church buildings, Den Haag, Kok Pharos Publishing House.

Lynch, Kevin

1960 The Image of the City, Cambridge, Massachusetts, and London, England, MIT University Press.

Manhattan Engineer District

1946 The Atomic Bombings of Hiroshima and Nagasaki, Public Domain.

Nenci, Cinzia (ed.)

2001 Restauro archeologico, Vol. 6, Firenze, Alinea.

Oliveira, Vitor

2016 Urban Morphology: An Introduction to the Study of the Physical Form of Cities, Berlin, Springer.

Parzysz, Bernard

2011 "From One Polygon to Another: A Distinctive Feature of Some Ottoman Minarets", in Nexus Network Journal 13(2):471-486.

Ragon, Michel

1985 “Architecture e mégastructures", Communications, 42, Paris, Seuil.

Sāmih, Kamal Ad- Dīn

1955 The Birth and Evolution of Minarets in Islam, in Bulletin of Faculty of Engineering, Cairo, Cairo University, 1955, pp. 155-71.

Vittorini, Elio

1974 La Sardegna come un'infanzia, in Le opere narrative, a cura di M. Corti, Milano, Mondadori.

Ruggero Ragonese is a research assistant in Semiotics at the University of Modena and Reggio Emilia. 